OPEN ACCESS

Edited by:

Attila Szabo,

University of Oslo, Norway

Reviewed by:

Anna Fogdell-Hahn,

Karolinska Institute (KI), Sweden

Chiara Cordiglieri,

Istituto Nazionale Genetica

Molecolare (INGM), Italy

*Correspondence:

Tamás Bíró

biro.tamas@med.unideb.hu

Specialty section:

This article was submitted

to Multiple Sclerosis and

Neuroimmunology,

a section of the journal

Frontiers in Immunology

Received: 15 August 2017

Accepted: 23 October 2017

Published: 10 November 2017

Citation:

Oláh A, Szekanecz Z and Bíró T (2017) Targeting Cannabinoid

Signaling in the Immune System:

"High"-ly Exciting Questions,

Possibilities, and Challenges.

Front. Immunol. 8:1487.

doi: 10.3389/fimmu.2017.01487

\section{Targeting Cannabinoid Signaling in the Immune System: "High"-ly Exciting Questions, Possibilities, and Challenges}

\author{
Attila Oláh ${ }^{1}$, Zoltán Szekanecz ${ }^{2}$ and Tamás Bíró ${ }^{3 *}$ \\ ${ }^{1}$ Department of Physiology, Faculty of Medicine, University of Debrecen, Debrecen, Hungary, ${ }^{2}$ Department of Internal \\ Medicine, Division of Rheumatology, Faculty of Medicine, University of Debrecen, Debrecen, Hungary, ${ }^{3}$ Department of \\ Immunology, Faculty of Medicine, University of Debrecen, Debrecen, Hungary
}

It is well known that certain active ingredients of the plants of Cannabis genus, i.e., the "phytocannabinoids" [pCBs; e.g., (-)-trans- $\Delta^{9}$-tetrahydrocannabinol (THC), (-)-cannabidiol, etc.] can influence a wide array of biological processes, and the human body is able to produce endogenous analogs of these substances ["endocannabinoids" (eCB), e.g., arachidonoylethanolamine (anandamide, AEA), 2-arachidonoylglycerol (2-AG), etc.]. These ligands, together with multiple receptors (e.g., $\mathrm{CB}_{1}$ and $\mathrm{CB}_{2}$ cannabinoid receptors, etc.), and a complex enzyme and transporter apparatus involved in the synthesis and degradation of the ligands constitute the endocannabinoid system (ECS), a recently emerging regulator of several physiological processes. The ECS is widely expressed in the human body, including several members of the innate and adaptive immune system, where eCBs, as well as several pCBs were shown to deeply influence immune functions thereby regulating inflammation, autoimmunity, antitumor, as well as antipathogen immune responses, etc. Based on this knowledge, many in vitro and in vivo studies aimed at exploiting the putative therapeutic potential of cannabinoid signaling in inflammation-accompanied diseases (e.g., multiple sclerosis) or in organ transplantation, and to dissect the complex immunological effects of medical and "recreational" marijuana consumption. Thus, the objective of the current article is (i) to summarize the most recent findings of the field; (ii) to highlight the putative therapeutic potential of targeting cannabinoid signaling; (iii) to identify open questions and key challenges; and (iv) to suggest promising future directions for cannabinoid-based drug development.

\footnotetext{
Keywords: cannabinoid signaling, endocannabinoid, inflammation, immune response, phytocannabinoid, multiple sclerosis, tumor immunology, marijuana
}

\section{INTRODUCTION}

\section{The Endocannabinoid System (ECS) and Its Connections in a Nutshell}

The ECS is a recently emerging, multifaceted signaling system, comprising various endogenous ligands [i.e., the "endocannabinoids" (eCBs), e.g., arachidonoylethanolamine (a.k.a. anandamide, AEA), 2-arachidonoylglycerol (2-AG), etc.], eCB-responsive receptors (e.g., $\mathrm{CB}_{1}$ and $\mathrm{CB}_{2}$ cannabinoid receptors, etc.), as well as enzymes and transporters involved in the synthesis 
[e.g., N-acyl phosphatidylethanolamine-specific phospholipase D (NAPE-PLD), diacylglycerol lipase- $\alpha$ and $-\beta$, protein tyrosine phosphatase non-receptor type 22 (PTPN22), etc.], cellular uptake/release [i.e., the putative endocannabinoid membrane transporter (EMT)], intracellular transport (various fatty acid-binding proteins) and degradation [e.g., fatty acid amide hydrolase (FAAH), monoacylglycrol lipase, cyclooxygenase 2 (COX2), etc.] of the eCBs (Figure 1) (1-10).

Moreover, in a wider sense, based on structural similarities and/or partial overlaps in the ligand affinities, many other receptors [e.g., the recently deorphanized metabotropic GPR18, GPR55, and GPR119, the intranuclear peroxisome proliferatoractivated receptors (PPARs), as well as several members of the transient receptor potential (TRP) ion channel superfamily] together with some of their endogenous ligands (e.g., palmitoylethanolamide, oleoylethanolamine) can be classified as "ECSrelated" entities (Figure 1) (11-14).

Besides the high number of ligands and potential receptors, complexity of the cannabinoid signaling is further increased by two phenomena: (i) the often observed biased agonism (i.e., when the same receptor exhibits signaling preference among its possible second messenger pathways depending on the actual ligand) of the metabotropic cannabinoid receptors $(15,16)$ and (ii) by their potential of forming heteromers either with each other, or with various other $\mathrm{G}$ protein-coupled receptors.

Indeed, $\mathrm{CB}_{1}$ is generally considered to signal through $\mathrm{G}_{\alpha \mathrm{i}}$ protein leading to a decrease in the intracellular cyclic adenosine monophosphate (cAMP) level, and activation of the $\beta$-arrestin 1 and 2 pathways. On one hand, signaling bias can lie in the "choice" of the ligand in preferring (i.e., activating with higher relative efficiency) the $\beta$-arrestin pathway(s) over the $G$ protein-coupled one or vice versa. On the other hand, in some cases coupling to $\mathrm{G}_{\alpha \mathrm{\alpha}}, \mathrm{G}_{\alpha \mathrm{q}}$, or $\mathrm{G}_{\alpha 12 / 13}$ proteins (leading to the elevation of cAMP level, activation of phospholipase $\mathrm{C}$, or Rho pathway, respectively) was also observed, adding an extra layer of complexity to $\mathrm{CB}_{1}$ signaling (Figure 2) (14-21). Importantly, similar to many other $\mathrm{G}$ protein-coupled receptors, biased signaling was described in case of $\mathrm{CB}_{2}$ or even in case of the "ECS-related" GPR18, GPR55, and GPR119 (14, 16, 19-22).

Moreover, without being exhaustive, $\mathrm{CB}_{1}$ was shown to form functional heteromers with, e.g., $\delta$ opioid receptor (DOR) (23), $\mathrm{A}_{2 \mathrm{~A}}$ adenosine receptor (24), $\mathrm{D}_{2}$ dopamine receptor (25), orexin-1 receptor (26), etc., whereas $\mathrm{CB}_{2}$ was proven to heteromerize with, e.g., CXCR4 chemokine receptor (27), or GPR55 (28). On top of that, functional cooperation between $\mathrm{CB}_{1}$ and several receptor tyrosine kinases was also observed [Figure 2; extensively reviewed in Ref. (19)].

Considering the above described complexity of the system, it is not surprising that, at least some parts of, the ECS is present in virtually every cell type of the human body, and it was shown to be involved in the regulation of a plethora of physiological processes. In the central nervous system (CNS), these processes include regulation of appetite, pain sensation, mood, and memory, whereas in the peripheral tissues, e.g., bone formation, spermatogenesis, sebum production, etc., and, maybe most importantly, immune functions $(7,29-37)$. Indeed, eCB signaling was shown to be an important orchestrator of both the innate and adaptive immune responses. Although there are some

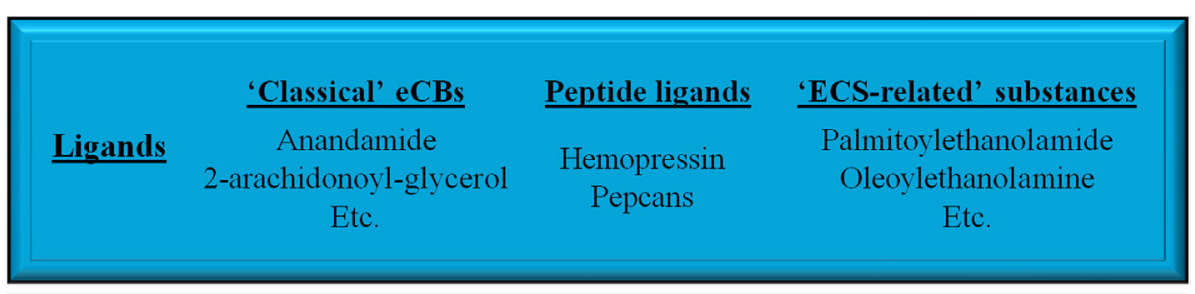

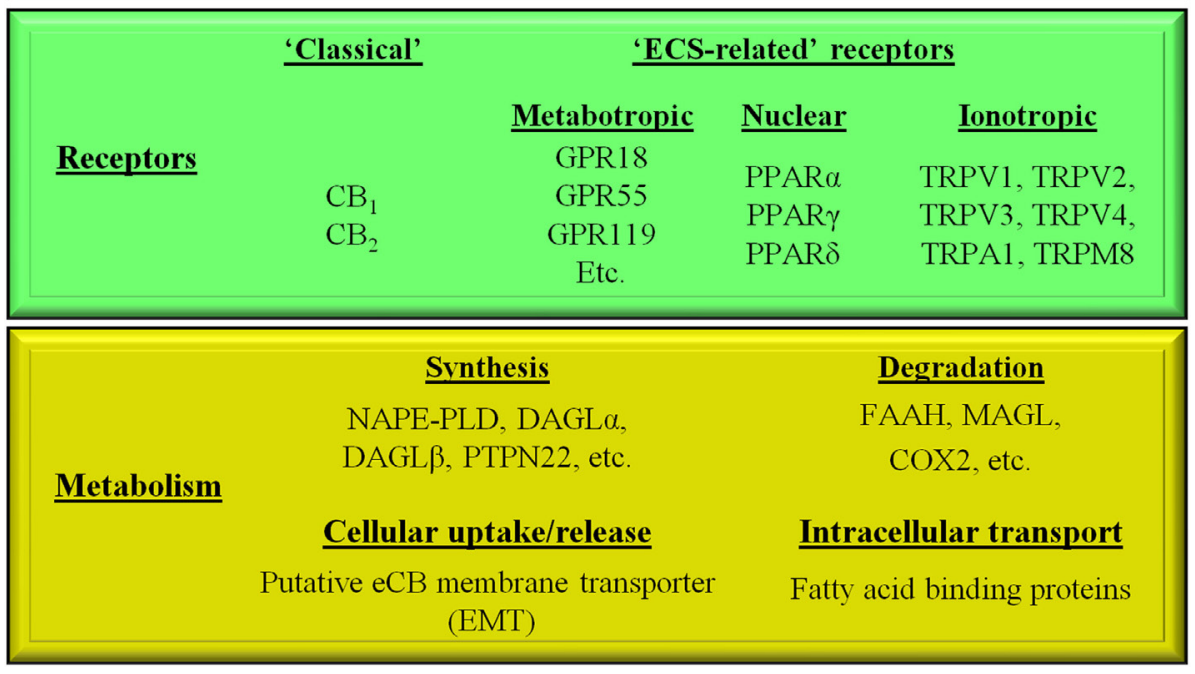

FIGURE 1 | Simplified overview of the endocannabinoid system. 


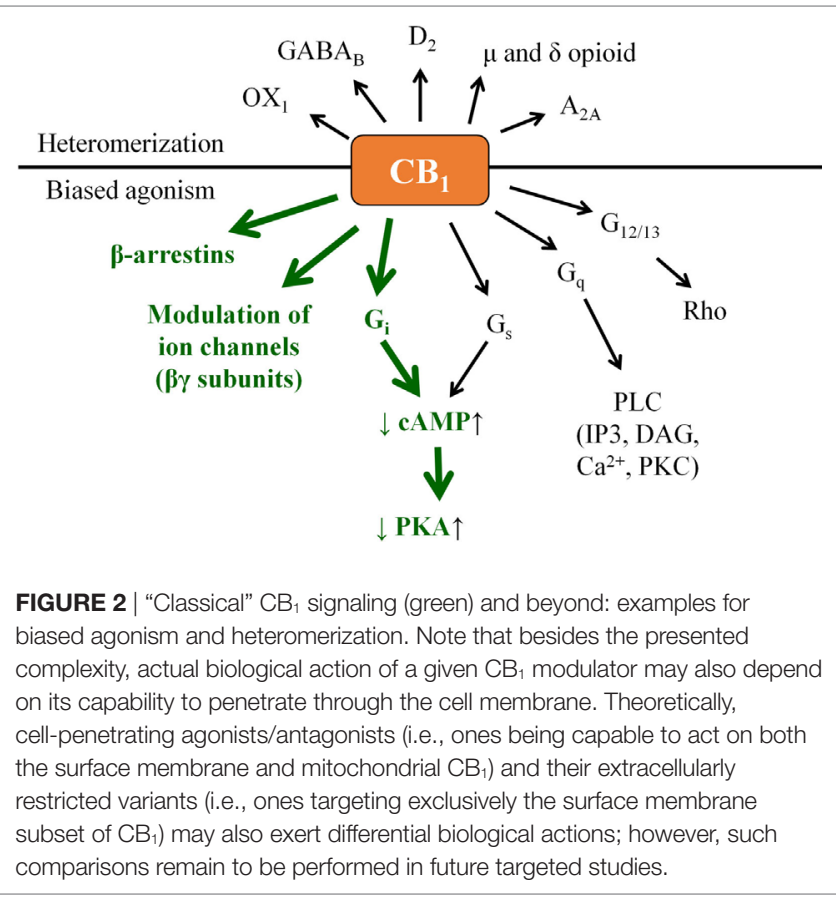

contradictions in the literature, ECS is generally considered to be a homeostatic "gate-keeper" of the immune system, preventing the onset of pathological, overwhelming proinflammatory responses. For example, $\mathrm{CB}_{1}$ and $\mathrm{CB}_{2}$ double $\mathrm{KO}$ mice exhibited stronger allergic inflammation than wild-type mice. Importantly, these alterations were shown to be mediated via the pathologically increased chemokine release of epidermal keratinocytes, suggesting that lack of homeostatic eCB signaling skewed keratinocytes toward a proinflammatory phenotype. On the other hand, $\mathrm{FAAH}^{-/-}$mice (having elevated eCB levels) showed reduced allergic responses (29), further arguing for the concept that elevation of the eCB tone (e.g., by abrogating degradation of the eCBs or by directly activating cannabinoid receptors) usually leads to potent anti inflammatory/antiallergic actions [extensively reviewed in, e.g., Ref. (7, 30, 31, 33, 34, 36-41)].

\section{Active Components of Cannabis sativa (Hemp) - Phytocannabinoids (pCBs) and Beyond}

It is known since ancient times that consumption of different parts of the plant Cannabis sativa can lead to psychotropic effects. Moreover, mostly, but not exclusively because of its potent analgesic actions, it was considered to be beneficial in the management of several diseases $(19,42,43)$. Nowadays it is a common knowledge that these effects were mediated by the complex mixture of biologically active substances produced by the plant. So far, at least 545 active compounds have been identified in it, among which, the best-studied ones are the so-called pCBs. It is also noteworthy that besides these compounds, ca. 140 different terpenes [including the potent and selective $\mathrm{CB}_{2}$ agonist sesquiterpene $\beta$-caryophyllene (BCP) (44)], multiple flavonoids, alkanes, sugars, non-cannabinoid

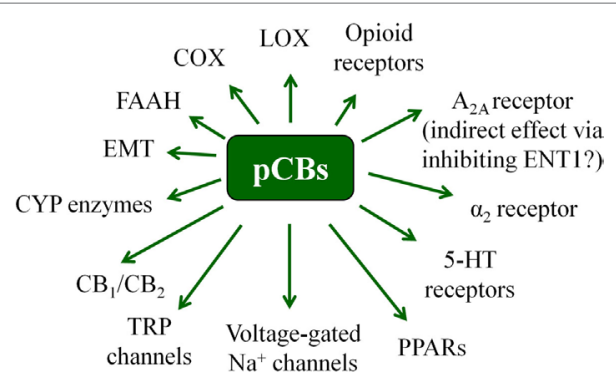

FIGURE 3 | Overview of the most important potential targets of the pCBs. Note that there are more than 100 pCBs in Cannabis sativa, and each of them can be characterized by a unique "molecular fingerprint." Obviously, every pCB is evidenced to interact with only a part of the potential targets presented on the figure. Moreover, the interactions can often lead to opposing molecular biology outcomes [e.g., THC is a partial $\mathrm{CB}_{1}$ agonist, whereas $\mathrm{CBD}$ is a $\mathrm{CB}_{1}$ antagonist/inverse agonist].

phenols, phenylpropanoids, steroids, fatty acids, and various nitrogenous compounds $(19,45,46)$ can be found in the plant, individual biological actions of which are mostly still nebulous. Among the so far identified $>100$ pCBs $(19,47)$, the psychotropic (-)-trans- $\Delta^{9}$-tetrahydrocannabinol (THC) and the non-psychotropic (-)-cannabidiol (CBD) are the best-studied ones, exerting a wide-variety of biological actions [including but not exclusively: anticonvulsive, analgesic, antiemetic, and anti inflammatory effects, etc.; for extensive reviews, see e.g., Ref. $(8,19)]$. Of great importance, pCBs have been shown to modulate the activity of a plethora of cellular targets, extending their impact far beyond the "classical" (see above) cannabinoid signaling. Indeed, besides being agonists [or in some cases even antagonists! (48)] of $\mathrm{CB}_{1}$ and $\mathrm{CB}_{2}$ cannabinoid receptors, some pCBs were shown to differentially modulate the activity of certain TRP channels, PPARs, serotonin, $\alpha$ adrenergic, adenosine or opioid receptors, and to inhibit COX and lipoxygenase enzymes, FAAH, EMT, etc. (8, 19, $48,49)$. Moreover, from a clinical point-of-view, it should also be noted that $\mathrm{pCBs}$ can indirectly modify pharmacokinetics of multiple drugs (e.g., cyclosporine A) by interacting with several cytochrome P 450 (CYP) enzymes (50, 51). Taken together, pCBs can be considered as multitarget polypharmacons, each of them having unique "molecular fingerprints" created by the characteristic activation/inhibition pattern of its locally available cellular targets (Figure 3) (52).

\section{SELECTED EPISODES OF "(PHYTO) CANNABINOID IMMUNOBIOLOGY"}

As we briefly mentioned above, ECS is generally considered to be one of the "gate-keepers" of the immune system, preventing the onset of pathological immune responses [extensively reviewed in Ref. $(7,30,31,33,34,36-41)]$. Considering that many of the aforementioned "non-classical" cannabinoid targets (e.g., TRP channels and PPARs) are also key regulators of the immune system (53-55), it is not surprising that both eCBs and pCBs can 
deeply influence immune responses. Based on this, elevation of the eCB tone and/or application of pCBs augur to be beneficial in those conditions, when one needs to suppress potentially detrimental immune responses (e.g., in organ transplantation or autoimmune diseases, etc.). However, administration of such medications may hold the risk of suppressing desired immunological reactions against pathogens and tumor cells.

Since clinical administration of medical marijuana as well as of purified/synthetic pCBs is nowadays under increasing scrutiny, in the next chapters we intend to summarize the most important data of the field, and, while also highlighting existing controversies and limitations, to point toward possible future directions of cannabinoid-based medicines (Table 1).

\section{Organ Transplantation}

In order to improve quality of life and life expectancy, prevention of acute and chronic rejection following solid organ transplantation, and avoidance of the development of graft-versus-host disease (GVHD) after bone marrow transplantation are key clinical challenges. Indeed, in order to overcome these problems, a number of different promising therapeutic opportunities are currently investigated, including, e.g., transplantation of tolerogenic dendritic cells (DCs) (56), modulation of myeloid-derived suppressor cells (MDSCs) (57) or regulatory T cells (Treg) (58), as well as inhibition of Janus kinase signaling (59), etc. Due to their well-described anti inflammatory effects, pCBs are also potential candidates to improve therapeutic protocols of transplantation (60).

The concept that positive modulation of cannabinoid signaling could be helpful in transplantation is supported by multiple pieces of evidence. Indeed, recent findings showed that cardiac allograft rejection was accelerated in $\mathrm{CB}_{2}{ }^{-1-}$ mice compared to wild-type recipients. In these experiments, bone marrow-derived dendritic cells (BM-DCs) of $\mathrm{CB}_{2}{ }^{-/-}$mice exhibited enhanced secretion of the proinflammatory cytokines interleukin (IL)- $1 \beta$, IL-6, and tumor necrosis factor, as well as transforming growth factor- $\beta 1$ upon Toll-like receptor (TLR) activation by lipopolysaccharide (LPS) or CpG. In addition, secretion of the Th1/ Th17-promoting IL-12 and IL-23 cytokines was also increased in $\mathrm{CB}_{2}^{-1-} \mathrm{BM}-\mathrm{DCs}$, and $\mathrm{CD}^{+} \mathrm{T}$ cells of the $\mathrm{KO}$ mice showed an enhanced capacity to differentiate into interferon (IFN)- $\gamma$ - or IL-17-producing effector cells, altogether suggesting that $\mathrm{CB}_{2}$ may be a potential therapeutic target in the clinical management of host-versus-graft reactions (61).

Importantly, not only $\mathrm{CB}_{2}$, but also $\mathrm{CB}_{1}$ emerged to be a promising therapeutic target in preventing organ rejection. Indeed, in mice, THC was recently found to attenuate hostversus-graft response and delayed rejection of skin graft by (i) reducing $\mathrm{T}$ cell proliferation and activation in draining lymph nodes of the recipient mice and (ii) decreasing early stage rejection-indicator cytokines, including IL-2 and IFN- $\gamma$. Moreover, by employing selective antagonists, as well as $\mathrm{CB}_{1}$ and $\mathrm{CB}_{2} \mathrm{KO}$ mice, the authors also showed that these effects were mediated via inducing MDSCs and activation of $\mathrm{CB}_{1}$ receptors (62).

Moreover, another study showed that, besides THC, CBD may also represent a promising novel treatment modality in organ transplantation (63), and administration of certain pCBs appeared to be promising in GVHD, too. Indeed, in an acute murine model of GVHD, THC (20 mg/kg i.p.) suppressed splenocyte transfer-induced weight loss, liver and intestinal tissue injury, as well as mortality. Importantly, THC treatment (i) reduced the expansion of donor-derived effector $\mathrm{T}$ cells; (ii) blocked the killing of host-derived immune cells; (iii) promoted Foxp $3^{+}$Treg cells; and (iv) normalized the impaired hematopoiesis seen during GVHD. The effects were thought to be $\mathrm{CB}_{1}$ - and $\mathrm{CB}_{2}$-mediated ones, since both $\mathrm{CB}_{1}$ (AM251) and $\mathrm{CB}_{2}$ (SR144528) specific inverse agonists were able to partially prevent the effect of THC in normalizing splenomegaly. Among them the $\mathrm{CB}_{2}$-selective SR144528 appeared to be more efficient, and the combination of the two inverse agonists could completely abrogate THC's beneficial effects arguing for that targeting $\mathrm{CB}_{1}$ and/or $\mathrm{CB}_{2}$ cannabinoid receptors may constitute a novel treatment modality against acute GVHD (64). Finally, data of a recent phase II clinical study (reference ID at clinicaltrials.gov: NCT01385124) showed that orally administered CBD (300 $\mathrm{mg} /$ day) is a safe and efficient way to improve the standard GVHD prophylaxis (65).

\section{Autoimmune Diseases}

The concept that dysregulation of the ECS can play a role in autoimmune diseases is supported by several lines of evidence. Indeed, the missense Arg $\rightarrow \operatorname{Trp}(\mathrm{R} 620 \mathrm{~W})$ polymorphism of the eCB synthesizing enzyme PTPN22 [encoding lymphoid protein tyrosine phosphatase (LYP), which is important in negatively controlling activation of T lymphocytes] was found to be associated with increased risk of type 1 diabetes mellitus (T1DM), rheumatoid arthritis (RA), juvenile idiopathic arthritis, systemic lupus erythematosus, Graves disease, myasthenia gravis, generalized vitiligo, and granulomatosis with polyangiitis [previously known as Wegener's granulomatosis; reviewed in Ref. (66)]. Moreover, a common dinucleotide polymorphism of $\mathrm{CB}_{2}$, resulting in a Gln $\rightarrow$ Arg substitution (Q63R), which is accompanied by a reduced capability of $\mathrm{CB}_{2}$-mediated signaling to suppress $\mathrm{T}$ cell proliferation (67), was associated with an increased risk of immune thrombocytopenia (68), and celiac disease (69). In line with these data, cooccurrence of Q63R polymorphism and immune-mediated disorders in chronic hepatitis $\mathrm{C}$ virus ( $\mathrm{HCV}$ ) infection was also observed (70), whereas the healthy $\mathrm{CB}_{2}$ variant was associated with more severe inflammation and hepatocellular necrosis, most probably because the intact $\mathrm{CB}_{2}$ could more efficiently inhibit antiviral $\mathrm{T}$ cell functions (71). Thus, the concepts to positively modulate eCB tone, to activate $\mathrm{CB}_{2}$ receptor and to administer certain pCBs has already been suggested in, e.g., RA, T1DM, autoimmune myocarditis, ulcerative colitis, Crohn's disease, etc. as well $(63,72-81)$, but so far, the "cannabinoid-wise" best explored autoimmune disease is unambiguously the multiple sclerosis (MS).

Indeed, AEA levels of the peripheral lymphocytes of MS patients was found to be elevated compared to healthy individuals, suggesting the development of a complex dysregulation in the ECS of MS patients $(82,83)$. Moreover, TLR and cannabinoid receptor cross-talk (84), as well as novel, "ECSrelated" receptors (GPR18 and GPR55) have all been suggested 
TABLE 1 | Overview of the compounds mentioned in the manuscript.

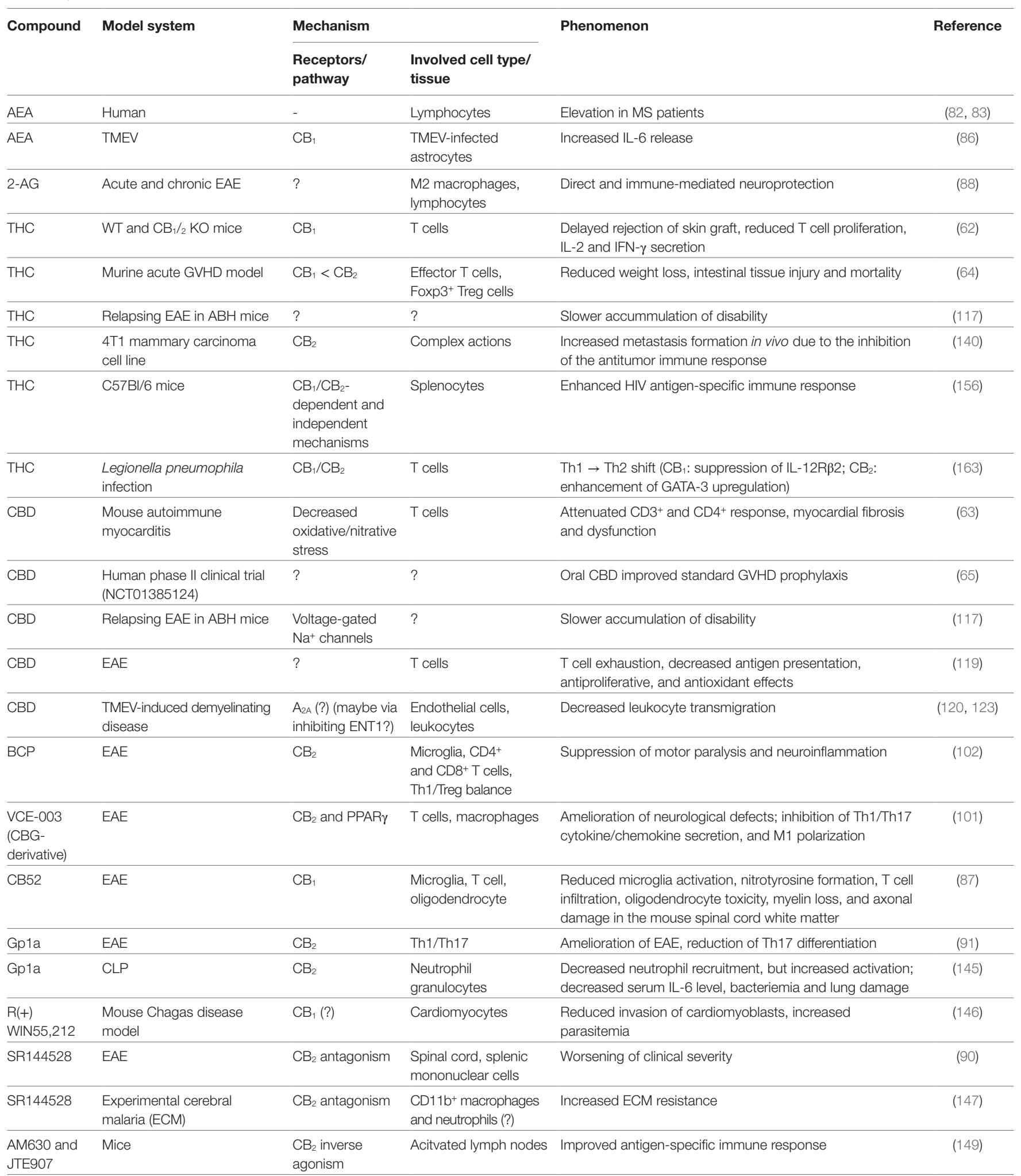

to play a role in the pathogenesis of MS (85), and $\mathrm{CB}_{1}$ (86-88), but especially $\mathrm{CB}_{2}$ also emerged as a remarkably powerful and multifaceted future therapeutic target in this disease (88-100).
In line with these data, daily administration of compound VCE-003 [a quinone derivative of the non-psychotropic pCB (-)-cannabigerol (CBG)] from day 6 postimmunization 
for 21 days was able to ameliorate the neurological defects and the severity of experimental autoimmune encephalomyelitis (EAE; a murine model of MS) induced by subcutaneous immunization with myelin oligodendrocyte glycoprotein $\left(\mathrm{MOG}_{35-55}\right.$; $300 \mu \mathrm{g})$ and Mycobacterium tuberculosis $(200 \mu \mathrm{g})$ in a 1:1 mix with incomplete Freund's adjuvant in mice. VCE-003 inhibited the secretion of Th1/Th17 cytokines and chemokines in primary murine $\mathrm{T}$ cells and dampened the IL-17-induced, proinflammatory $\mathrm{M} 1$ polarization of macrophages in a $\mathrm{CB}_{2}$ and PPAR $\gamma$ dependent manner (101). In line with these data, BCP suppressed motor paralysis and neuroinflammation in EAE by inhibiting microglial cells, $\mathrm{CD}^{+}$and $\mathrm{CD}^{+} \mathrm{T}$ lymphocytes, as well as protein expression of proinflammatory cytokines. Furthermore, it diminished axonal demyelination and modulated Th1/Treg immune balance through the activation of $\mathrm{CB}_{2}$ (102).

With respect to the "classical" pCBs, beneficial effects of Sativex $^{\circledR}$ (a buccal spray, which contains THC and CBD in a 1:1 ratio) and other pCB-based formulations in alleviating symptoms (e.g., spasticity, sleeping difficulty, neurogenic lower urinary tract dysfunction, gait, etc.) of MS are also well-described (103-111). However, since there are some controversies in the available data $(112,113)$, their long-term efficiency needs to be further investigated $(108,114)$. The necessity of such studies is further underscored by the findings of a recently conducted, small clinical trial, in which Bedrocan ${ }^{\circledR}$ (medical-grade cannabis, practically lacking CBD) was found to be effective in alleviating spasticity in $85 \%$ of Nabiximols (United States Adopted Name of Sative ${ }^{\circledR}$ ) non-responder patients (115), highlighting how deeply the exact composition of each pCB-based medication can influence the clinical efficacy.

Importantly, a growing body of evidence supports the concept that, besides providing symptomatic relief, treatment with appropriately selected pCBs may even have therapeutic value in MS. Indeed, an early study demonstrated that in EAE, THC-treated animals had either no or mild clinical symptoms with a survival greater than $95 \%$, whereas more than $98 \%$ of the animals died in the placebo group. The better survival was accompanied by a marked reduction of inflammation in the CNS of THC-treated animals (116). Partially in line with these data, in a 3-year, phase III clinical trial (albeit the authors did not detect a beneficial effect of oral THC in progressive MS in general) a thorough subgroup analysis of people with less disability and more rapid progression demonstrated a significant deceleration of disease development in the oral THC group compared to placebo (117).

In another study, synthetic CBD could slow down the accumulation of disability from the inflammatory penumbra during relapsing $\mathrm{EAE}$ in $\mathrm{ABH}$ mice, possibly via blocking voltagegated $\mathrm{Na}^{+}$channels. In addition, non-sedating doses of THC dose-dependently inhibited the accumulation of disability during EAE (117). According to another EAE study, in which CBD was applied after the development of the disease, CBD $(10 \mathrm{mg} / \mathrm{kg}$ mouse, i.p.) reversed EAE-induced downregulation of the phosphoinositide 3-kinase, protein kinase B (Akt), and mammalian/ mechanistic target of rapamycin (mTOR) in the spinal cord. Moreover, $\mathrm{CBD}$ increased brain-derived neurotrophic factor level, downregulated IFN- $\gamma$ and IL-17, upregulated PPAR $\gamma$, and was found to promote neuronal survival by inhibiting c-Jun N-terminal kinase and p38 mitogen-activated protein kinase (118). Furthermore, another group demonstrated that in EAE, CBD exerted its immunoregulatory effects in activated $\mathrm{MOG}_{35-55}$-specific memory $\mathrm{T}$ cell cells via (i) suppressing proinflammatory Th17-related transcription; (ii) promoting $\mathrm{T}$ cell exhaustion/tolerance; (iii) enhancing IFN-dependent antiproliferative program; (iv) hampering antigen presentation; and (v) inducing antioxidant milieu resolving inflammation (119).

In line with the above data, CBD was found to be protective in Theiler's encephalomyelitis virus (TMEV)-induced demyelinating disease (a viral model of MS) via activating $\mathrm{A}_{2 \mathrm{~A}}$ receptors (120). It is noteworthy that although $\mathrm{A}_{2 \mathrm{~A}}$ receptor most probably does not bind $\mathrm{CBD}$, the phenomenon that it can mediate anti inflammatory actions of this pCB is not unprecedented. Indeed, similar effects were shown in murine acute lung injury model (121) and in human sebocytes (122) too, and they were thought to be realized via the inhibition of equilibrative nucleoside transporter(s) (e.g., ENT1, which mediates adenosine uptake of the cells) and the subsequently elevated "adenosine tone" (123).

\section{Tumor Immunology}

Besides that medical marijuana is increasingly used in various tumors as a palliative treatment option (124), exploitation of the putative antitumor therapeutic potential of the endo- and pCBs is a hot topic of today's cannabinoid research. Via activating $\mathrm{CB}_{1}$, $\mathrm{CB}_{2}$, or other cellular targets, both endo- and $\mathrm{pCBs}$ were already convincingly shown to exert complex [e.g., antiproliferative and proapoptotic effects, inhibition of angiogenesis, inhibition of tumor cell chemotaxis via activating $\mathrm{CB}_{2}$ /CXCR4 heteromers, etc. $(27,125-134)]$ antitumor effects in most of the test systems in vitro. Although there are some exceptions [e.g., engagement of $\mathrm{CB}_{1}$ and $\mathrm{CB}_{2}$ were found to promote tumor progression in human melanoma cells $\left(\mathrm{CB}_{1}\right)$, in renal cell carcinoma $\left(\mathrm{CB}_{1}\right)$, as well as in colon cancer $\left.\left(\mathrm{CB}_{2}\right)(135-137)\right]$, most studies agree that their putative beneficial antitumor effects deserves further scrutiny $(138,139)$. However, several lines of evidence argue for that promising in vitro antitumor data cannot necessarily be translated to in vivo clinical benefits, because of the cannabinoidmediated suppression of the antitumor (Th1-dominated) immune response $(138,139)$. Indeed, by investigating human (MCF-7 and MDA-MB-231) and mouse (4T1) mammary carcinoma cell lines expressing low to undetectable levels of $\mathrm{CB}_{1}$ and $\mathrm{CB}_{2}$, McKallip et al. found that these cells were not only resistant to THC-induced cytotoxicity, but THC treatment led to elevated $4 \mathrm{~T} 1$ tumor growth and metastasis due to $\mathrm{CB}_{2}$-mediated inhibition of the antitumor immune response (140). Thus, although the very few available human studies [reviewed in Ref. (139)] suggest that THC and cannabis-extracts may have some beneficial effects beyond mere palliation, well-controlled, further studies are invited to find the most appropriate place of cannabinoid medications in the antitumoral therapeutic repertoire.

\section{Defense against Pathogens}

Theoretically, administration of endo- and pCBs may hold the risk of dampening appropriate immune responses, and thereby 
increasing susceptibility toward infectious diseases. However, in light of the literature data, the situation appears to be more complex. Indeed, certain control over the overwhelming inflammatory processes in, e.g., systemic inflammatory response syndrome or sepsis would be undoubtedly highly desirable (141-143). Within the "classical" ECS, the anti inflammatory $\mathrm{CB}_{2}$ appears to be the most promising candidate to adjust such immune responses, but recently other receptors (e.g., $\mathrm{CB}_{1}$ or the apparently rather proinflammatory GPR55) were also proven to be potent and relevant regulators. The available (somewhat controversial) data about the roles of these receptors in sepsis, and especially the possible therapeutic exploitation of GPR55-antagonism in such conditions, is extensively reviewed in Ref. (34).

With respect to $\mathrm{CB}_{2}$, it has recently been shown that loss of homeostatic $\mathrm{CB}_{2}$ signaling worsened LPS-induced sepsis in mice, whereas activation of $\mathrm{CB}_{2}$ was proven to be beneficial via reducing leukocyte endothelial interactions, and thereby preventing further inflammatory damage (144). Similarly, in a cecal ligation and puncture (CLP) model of sepsis, $\mathrm{CB}_{2}{ }^{-1-}$ mice exhibited higher serum IL-6 levels and bacteremia, and had decreased survival rates, whereas $\mathrm{CB}_{2}$ agonism increased the mean survival time in wild-type mice (145). Furthermore, in a mice model of Trypanosoma cruzi infection (Chagas disease) it was shown that the non-specific $\mathrm{CB}$ receptor agonist $\mathrm{R}(+)$ WIN55,212 significantly reduced cardiac inflammation. However, it also led to considerably increased parasitemia, therefore therapeutic value of such non-specific drugs remained questionable (146).

In contrast to the aforementioned findings, in a mice model of cerebral malaria (a severe and often fatal complication of Plasmodium falciparum infection), $\mathrm{CB}_{2}$ antagonism, as well as the $\mathrm{CB}_{2}^{-1-}$ genotype were protective, and led to enhanced survival and a diminished blood-brain barrier disruption (147). Moreover, $\mathrm{CB}_{2}^{-1-}$ (but not $\mathrm{CB}_{1}^{-l-}$ ) mice were resistant to LPSdriven suppression of serum progesterone levels and preterm birth (148). Last, but not least, transient administration of the $\mathrm{CB}_{2}$ inverse agonists AM630 (10 mg/kg) or JTE907 (3 mg/kg) during immunization was found to improve antigen-specific immune responses in young and aged mice through the upregulation of immunomodulatory genes in secondary lymphoid tissues (149).

Thus, in light of the above data, it seems to be highly likely that both enhancement and suppression of the eCB signaling might have therapeutic value in carefully selected clinical conditions, which already suggests that administration of pCBs and/or other cannabis-derivatives is also not without controversies. Indeed, although several pCBs were shown to exert potent direct antibacterial activity (150), their aforementioned immunosuppressive effects definitely limit their therapeutic administration in infections. Since excellent overviews of the effects of pCBs and the ECS in viral (151), and other infections (34) were published recently, here we will only highlight some of the most interesting controversies of the field.

Without being exhaustive, in a Wistar rat model of pneumococcal meningitis, CBD (10 mg/kg, i.p.) reduced host immune response, and prevented cognitive impairments (152). Chronic administration of THC induced intestinal anti-inflammatory miRNA expression during acute Simian Immunodeficiency Virus (SIV) infection of rhesus macaques (153), and did not increase viral load in brain tissue (154). Likewise, another study also showed that chronic THC administration did not increase viral load or aggravate morbidity; in contrast, it could actually ameliorate SIV disease progression, via retention of body mass, and attenuation of inflammation (155). Moreover, it was also shown that under certain conditions, THC could even enhance Human Immunodeficiency Virus (HIV) antigenspecific immune responses, which occurred through both $\mathrm{CB}_{1} /$ $\mathrm{CB}_{2}$-dependent and -independent mechanisms (156), and findings showed no evidence for a negative effect of cannabis use on circulating $\mathrm{CD}^{+} \mathrm{T}$ cell counts/percentages in HCV-HIV coinfected patients (157). Thus, it is not surprising that medical marijuana is part of HIV/AIDS adjuvant treatment in several countries (158).

With respect to other infections, it is noteworthy that CBD was recently suggested to be explored as a treatment for individuals suffering from post-Ebola syndrome (159). Moreover, although it had no effect on Hepatitis B Virus, $10 \mu \mathrm{M}$ CBD inhibited HCV replication by $86.4 \%$ in vitro (160). Finally, CBD $(30 \mathrm{mg} / \mathrm{kg} /$ day, i.p.) increased survival, and promoted rescue of cognitive function in a murine model of cerebral malaria (161).

Despite these promising findings, data of some other studies argue against the administration of pCBs in infectious diseases. Indeed, chronic THC treatment decreased the efficacy of the memory immune response to Candida infection (162). In Legionella pneumophila infection, THC treatment prior to contamination induced a shift from Th1 to Th2 immunity in a $\mathrm{CB}_{1}$ and $\mathrm{CB}_{2}$ dependent manner (163). Moreover, THC impaired the inflammatory response to influenza infection (164), suppressed immune function, and enhanced HIV replication in a mice model, where human peripheral blood leukocytes (PBLs) were implanted into severe combined immunodeficient mice (huPBL-SCID mice) (165). Interestingly, investigation of plasmocytoid dendritic cells (pDCs) revealed an intriguing functional heterogeneity of the $\mathrm{pCBs}$, i.e., THC (but not CBD!) suppressed secretion of IFN- $\alpha$ by $\mathrm{pDC}$ from both healthy and $\mathrm{HIV}^{+}$donors, arguing for that although $\mathrm{THC}$ may impair antiviral responses, but this may also be protective in neuroinflammation associated with prolonged HIV infection (166). Taken together, these data suggest that although cannabinoid signaling may decrease the efficiency of certain antipathogen immune responses, in some cases it might still be beneficial by limiting overwhelming inflammatory response and tissue destruction. Further studies are therefore invited to determine and exploit exact therapeutic value of eCBs and pCBs in such diseases.

\section{COMPLEX IMMUNOLOGICAL EFFECTS OF MEDICAL AND "RECREATIONAL" MARIJUANA CONSUMPTION}

Considering the wide-spread popularity of marijuana consumption and the social debate about its legislative status, it 
is clear that there is an emerging demand from the scientific community, the society, as well as from the decision makers to design further in vitro and in vivo studies to better characterize biological actions and potential risks of marijuana and other cannabis derivatives. This is especially urging since even habitual exposure to THC appears to be capable of impacting on human cell-mediated immunity and host defense (167). Moreover, recent animal studies showed that parental or prenatal exposure to cannabis could trigger epigenetic changes that led to significant transgenerational immunological consequences (168). Indeed, perinatal exposure of mice to THC was found to trigger profound $\mathrm{T}$ cell dysfunction, thereby suggesting that children of marijuana abusers who have been exposed to THC in utero, may be at a higher risk of exhibiting immune dysfunction and contracting infectious diseases including HIV infection (169). Following up the line of the possible long-term consequences of marijuana consumption, it is important to note that although acute THC exposure in adolescent mice is anti inflammatory, it also has long-lasting proinflammatory effects on brain cytokines, and this modulation may affect vulnerability to immune and behavioral diseases in adulthood $(170,171)$.

Intriguingly, in spite of the above data, in an early doubleblind, placebo-controlled human study no endocrine or immunological alterations were observed upon THC use (172). However, a more recent study, which aimed to assess the effects of medical cannabis ingestion on peripheral blood mononuclear cells, revealed an immunosuppressive effect of cannabinoid preparations via deactivation of signaling through the proinflammatory p38 MAP kinase and mTOR pathways and a concomitant deactivation of the promitogenic $\mathrm{p} 42 / \mathrm{p} 44$ extracellular signalregulated kinase (ERK)-1/2 signaling. However, it should also be noted that long-term cannabis exposure in two patients resulted in reversal of this effect (173). Similar to these data, a significant decrease in serum immunoglobulin (IgG and IgM) levels, in C3 and $\mathrm{C} 4$ complement protein concentrations, as well as in absolute numbers of $\mathrm{T}$ and $\mathrm{B}$ lymphocytes and natural killer (NK) cells was observed in bhang (an edible form of cannabis) users as compared to controls. Interestingly, FAAH (the major eCBdegrading enzyme) expression also showed significant decrease in lymphocytes of these subjects (174).

\section{OPEN QUESTIONS, FUTURE CHALLENGES, AND PERSPECTIVES}

Although research efforts of the last three decades provided an extremely large (and ever increasing) body of evidence, there are still significant gaps in our understanding with respect to the cannabinoid signaling, and its optimal therapeutic exploitation, inviting obviously a number of specific complementary in vitro, in vivo and clinical studies. Along these lines, several important challenges should be faced and handled.

\section{Potential Side Effects}

From the point-of-view of future drug development, the most obvious challenge is to avoid potential psychotropic and cardiac side effects, as well as development of tolerance and dependence due to activation of $\mathrm{CB}_{1}$ [overviewed in Ref. (8)]. Moreover, administration of THC and activation of $\mathrm{CB}_{1}$ were shown to lead to memory impairment, most probably due to the activation of the recently discovered, mitochondrially expressed subset of the receptor $(175,176)$, suggesting that extracellularly restricted $\mathrm{CB}_{1}$ agonists may be devoid of such side effects. Development of such compounds can therefore be a promising future direction in cannabinoid-based experimental pharmacology. Interestingly, however, it should also be noted that memoryimpairing effect of $\mathrm{CB}_{1}$ activation appears to be age-dependent; in fact, THC $\mathrm{CB}_{1}$-dependently improved memory function in aged mice (177). Furthermore, by using $\mathrm{CB}_{1}{ }^{-/-}$mice, it has also been demonstrated that lack of homeostatic $\mathrm{CB}_{1}$ signaling leads to a premature decline in cognitive abilities (178), and chronic THC administration-induced dramatic and sustained downregulation of $\mathrm{CB}_{1}$ was also suggested to play a role in cannabisinduced cognitive dysfunction (179). Altogether, these data clearly indicate that memory problems can occur on the basis of both overactivation and critical impairment of $\mathrm{CB}_{1}$ signaling. Considering the aforementioned, somewhat confusing data, focused studies are definitely required to exclude potential memory-impairing side effects of any future brain-penetrating $\mathrm{CB}_{1}$ agonists before their clinical administration.

On the other hand, we should also keep in mind that antagonism/inverse agonism of $\mathrm{CB}_{1}$ located in the CNS can also lead to serious neuropsychiatric side effects (including suicide), as it became evidenced by the infamous, brain-penetrating $\mathrm{CB}_{1}$ inverse agonist rimonabant (SR141716; trade names: Acomplia and Zimulti), which was applied as a potent anorexigenic agent for a few years in Europe, but was then retracted from the market (180). Fortunately, keeping $\mathrm{CB}_{1}$ modulators out from the CNS can relatively easily be solved by designing peripherally restricted molecules, which cannot penetrate through the blood-brain barrier.

It should also be mentioned that in a recent phase 1 trial administration of a FAAH-inhibitor named "BIA 10-2474" led to the death of one volunteer and produced mild-to-severe neurological symptoms in four others $(181,182)$. Importantly, it has been proven that BIA 10-2474 was a very unspecific, promiscuous lipase inhibitor, and that fatal side effects most probably developed due to a complex metabolic dysregulation in the CNS caused by the inhibition of some of its off-targets, which underscores the importance of rigorous preclinical testing of any drug candidates which are planned to be applied in human studies.

\section{Variable Composition of Cannabis- Derivatives, Impact of Cannabis Use History of the Patients}

Clinical efficiency of complex cannabis-derivatives may greatly depend on their exact composition (115), since beyond the pCBs (each of which already possesses remarkably complex, unique molecular fingerprint), they contain many other biologically active, non-pCB components as well. Therefore, it is crucially important to describe biological actions and identify cellular 
targets of these so far neglected components in well-controlled future studies.

Unfortunately, rigorous assessment of pCBs' clinical efficiency is complicated by several factors. Indeed, in a recent study, Scott et al. found that the combination of THC and CBD was more effective in killing HL60 leukemia cells than the individually applied pCBs. Even more importantly, using cannabinoids after the chemotherapy resulted in greater induction of apoptosis (183), highlighting that even the schedule of administration may influence the measured efficiency.

Another important issue which should be kept in mind while interpreting results of studies involving cannabis users is how well-controlled and reliable those prospective and retrospective human studies are. First, self-admission about the history of marijuana consumption may be misguiding. Second, due to the aforementioned "transgenerational" effects (168-171), in an "ideal" clinical study, inclusion/exclusion criteria should also consider "family history" of marijuana consumption. Third, purity/quality of the self-administered marijuana, as well as exposure to other illicit drugs, to alcohol (184), or to drugs belonging to the "gray zone," e.g., novel psychoactive substances [NPS, a.k.a. "designer drugs"; synthetic, psychoactive substances that are generally not (yet) under international regulatory control, and among which several synthetic cannabinoids are now present at the black market (185)] should also be explored, since these all can deeply influence immunological effects of acutely applied pCBs, thereby falsifying the results [e.g., acute application of pCBs was found to significantly inhibit both the basal and $\mathrm{C}-\mathrm{C}$ motif chemokine ligand 2 (CCL2)-stimulated migration of monocytes, but only in individuals non-naive to Cannabis (186)].

\section{REFERENCES}

1. Pertwee RG, Howlett AC, Abood ME, Alexander SPH, Di Marzo V, Elphick MR, et al. International Union of Basic and Clinical Pharmacology. LXXIX. Cannabinoid receptors and their ligands: beyond CB1 and CB2. Pharmacol Rev (2010) 62:588-631. doi:10.1124/pr.110.003004

2. Păunescu H, Coman OA, Coman L, Ghiţă I, Georgescu SR, Drăghia F, et al. Cannabinoid system and cyclooxygenases inhibitors. JMed Life (2011) 4:11-20.

3. Chicca A, Marazzi J, Nicolussi S, Gertsch J. Evidence for bidirectional endocannabinoid transport across cell membranes. JBiol Chem (2012) 287:34660-82. doi:10.1074/jbc.M112.373241

4. Abood ME, Sorensen RG, Stella N, editors. endoCANNABINOIDS. New York, NY: Springer (2013). Available from: http://link.springer.com/10. 1007/978-1-4614-4669-9

5. Kaczocha M, Rebecchi MJ, Ralph BP, Teng Y-HG, Berger WT, Galbavy W, et al. Inhibition of fatty acid binding proteins elevates brain anandamide levels and produces analgesia. PLoS One (2014) 9:e94200. doi:10.1371/journal.pone.0094200

6. Di Marzo V, Piscitelli F. The endocannabinoid system and its modulation by phytocannabinoids. Neurotherapeutics (2015) 12:692-8. doi:10.1007/ s13311-015-0374-6

7. Maccarrone M, Bab I, Bíró T, Cabral GA, Dey SK, Di Marzo V, et al. Endocannabinoid signaling at the periphery: 50 years after THC. Trends Pharmacol Sci (2015) 36:277-96. doi:10.1016/j.tips.2015.02.008

8. Ligresti A, De Petrocellis L, Di Marzo V. From phytocannabinoids to cannabinoid receptors and endocannabinoids: pleiotropic physiological and pathological roles through complex pharmacology. Physiol Rev (2016) 96:1593-659. doi:10.1152/physrev.00002.2016

\section{CONCLUDING REMARKS-LESSONS TO LEARN FROM Cannabis}

Research efforts of the past few decades have unambiguously evidenced that ECS is one of the central orchestrators of both innate and adaptive immune systems, and that pure pCBs as well as complex cannabis-derivatives can also deeply influence immune responses. Although, many open questions await to be answered, pharmacological modulation of the (endo)cannabinoid signaling, and restoration of the homeostatic eCB tone of the tissues augur to be very promising future directions in the management of several pathological inflammationaccompanied diseases. Moreover, in depth analysis of the (quite complex) mechanism-of-action of the most promising pCBs is likely to shed light to previously unknown immune regulatory mechanisms and can therefore pave new "high"-ways toward developing completely novel classes of therapeutic agents to manage a wide-variety of diseases.

\section{AUTHOR CONTRIBUTIONS}

All authors wrote, edited, and approved the final version of this manuscript.

\section{FUNDING}

Preparation of this manuscript was supported by Hungarian (NRDIO 120552, 121360, and 125055), as well as EU (GINOP2.3.2-15-2016-00050) research grants. AO's work was supported by the János Bolyai Research Scholarship of the Hungarian Academy of Sciences.

9. Chicca A, Nicolussi S, Bartholomäus R, Blunder M, Aparisi Rey A, Petrucci V, et al. Chemical probes to potently and selectively inhibit endocannabinoid cellular reuptake. Proc Natl Acad Sci U S A (2017) 114:E5006-15. doi:10.1073/pnas.1704065114

10. Maccarrone M. Metabolism of the endocannabinoid anandamide: open questions after 25 years. Front Mol Neurosci (2017) 10:166. doi:10.3389/ fnmol.2017.00166

11. Godlewski G, Offertáler L, Wagner JA, Kunos G. Receptors for acylethanolamides-GPR55 and GPR119. Prostaglandins Other Lipid Mediat (2009) 89:105-11. doi:10.1016/j.prostaglandins.2009.07.001

12. Caterina MJ. TRP channel cannabinoid receptors in skin sensation, homeostasis, and inflammation. ACS Chem Neurosci (2014) 5:1107-16. doi:10.1021/cn5000919

13. O'Sullivan SE. An update on PPAR activation by cannabinoids. Br J Pharmacol (2016) 173:1899-910. doi:10.1111/bph.13497

14. Laprairie RB, Bagher AM, Denovan-Wright EM. Cannabinoid receptor ligand bias: implications in the central nervous system. Curr Opin Pharmacol (2017) 32:32-43. doi:10.1016/j.coph.2016.10.005

15. Ibsen MS, Connor M, Glass M. Cannabinoid CB1 and CB2 receptor signaling and bias. Cannabis Cannabinoid Res (2017) 2:48-60. doi:10.1089/ can.2016.0037

16. Soethoudt M, Grether U, Fingerle J, Grim TW, Fezza F, de Petrocellis L, et al. Cannabinoid CB2 receptor ligand profiling reveals biased signalling and off-target activity. Nat Commun (2017) 8:13958. doi:10.1038/ ncomms 13958

17. Nogueras-Ortiz C, Yudowski GA. The multiple waves of cannabinoid 1 receptor signaling. Mol Pharmacol (2016) 90:620-6. doi:10.1124/mol.116.104539

18. Ford BM, Franks LN, Tai S, Fantegrossi WE, Stahl EL, Berquist MD, et al. Characterization of structurally novel $G$ protein biased $\mathrm{CB}$ 
agonists: implications for drug development. Pharmacol Res (2017) 125:161-77. doi:10.1016/j.phrs.2017.08.008

19. Solymosi K, Köfalvi A. Cannabis: a treasure trove or pandora's box? Mini Rev Med Chem (2017) 17:1223-91. doi:10.2174/1389557516666161 004162133

20. Mallipeddi S, Janero DR, Zvonok N, Makriyannis A. Functional selectivity at G-protein coupled receptors: advancing cannabinoid receptors as drug targets. Biochem Pharmacol (2017) 128:1-11. doi:10.1016/j. bcp.2016.11.014

21. Priestley R, Glass M, Kendall D. Functional selectivity at cannabinoid receptors. Adv Pharmacol (2017) 80:207-21. doi:10.1016/bs.apha.2017. 03.005

22. Hassing HA, Fares S, Larsen O, Pad H, Hauge M, Jones RM, et al. Biased signaling of lipids and allosteric actions of synthetic molecules for GPR119. Biochem Pharmacol (2016) 119:66-75. doi:10.1016/j.bcp.2016. 08.018

23. Rozenfeld R, Bushlin I, Gomes I, Tzavaras N, Gupta A, Neves S, et al. Receptor heteromerization expands the repertoire of cannabinoid signaling in rodent neurons. PLoS One (2012) 7:e29239. doi:10.1371/journal. pone. 0029239

24. Lazzerini PE, Natale M, Gianchecchi E, Capecchi PL, Montilli C, Zimbone $\mathrm{S}$, et al. Adenosine A2A receptor activation stimulates collagen production in sclerodermic dermal fibroblasts either directly and through a cross-talk with the cannabinoid system. J Mol Med (Berl) (2012) 90:331-42. doi:10.1007/s00109-011-0824-5

25. Bagher AM, Laprairie RB, Toguri JT, Kelly MEM, Denovan-Wright EM. Bidirectional allosteric interactions between cannabinoid receptor 1 (CB1) and dopamine receptor 2 long (D2L) heterotetramers. Eur J Pharmacol (2017) 813:66-83. doi:10.1016/j.ejphar.2017.07.034

26. Ward RJ, Pediani JD, Milligan G. Heteromultimerization of cannabinoid $\mathrm{CB}(1)$ receptor and orexin $\mathrm{OX}(1)$ receptor generates a unique complex in which both protomers are regulated by orexin A. J Biol Chem (2011) 286:37414-28. doi:10.1074/jbc.M111.287649

27. Coke CJ, Scarlett KA, Chetram MA, Jones KJ, Sandifer BJ, Davis AS, et al. Simultaneous activation of induced heterodimerization between CXCR4 chemokine receptor and cannabinoid receptor 2 (CB2) reveal a mechanism for regulation of tumor progression. J Biol Chem (2016) 291: 9991-10005. doi:10.1074/jbc.M115.712661

28. Balenga NA, Martínez-Pinilla E, Kargl J, Schröder R, Peinhaupt M, Platzer W, et al. Heteromerization of GPR55 and cannabinoid CB2 receptors modulates signalling. Br J Pharmacol (2014) 171:5387-406. doi:10.1111/ bph. 12850

29. Karsak M, Gaffal E, Date R, Wang-Eckhardt L, Rehnelt J, Petrosino S, et al. Attenuation of allergic contact dermatitis through the endocannabinoid system. Science (2007) 316:1494-7. doi:10.1126/science.1142265

30. Chiurchiù V, Battistini L, Maccarrone M. Endocannabinoid signaling in innate and adaptive immunity. Immunology (2015) 144:352-64. doi:10.1111/ imm. 12441

31. Chiurchiù V. Endocannabinoids and immunity. Cannabis Cannabinoid Res (2016) 1:59-66. doi:10.1089/can.2016.0002

32. Oláh A, Ambrus L, Nicolussi S, Gertsch J, Tubak V, Kemény L, et al. Inhibition of fatty acid amide hydrolase exerts cutaneous anti-inflammatory effects both in vitro and in vivo. Exp Dermatol (2016) 25:328-30. doi:10.1111/ exd. 12930

33. Oláh A, Bíró T. Targeting cutaneous cannabinoid signaling in inflammation - a "high"-way to heal? EBioMedicine (2017) 16:3-5. doi:10.1016/j. ebiom.2017.01.003

34. Zhou J, Burkovskiy I, Yang H, Sardinha J, Lehmann C. CB2 and GPR55 receptors as therapeutic targets for systemic immune dysregulation. Front Pharmacol (2016) 7:264. doi:10.3389/fphar.2016.00264

35. Lu Y, Anderson HD. Cannabinoid signaling in health and disease. Can J Physiol Pharmacol (2017) 95:311-27. doi:10.1139/cjpp-2016-0346

36. McCoy KL. Interaction between cannabinoid system and toll-like receptors controls inflammation. Mediators Inflamm (2016) $2016: 5831315$. doi:10.1155/2016/5831315

37. Cabral GA, Rogers TJ, Lichtman AH. Turning over a new leaf: cannabinoid and endocannabinoid modulation of immune function. J Neuroimmune Pharmacol (2015) 10:193-203. doi:10.1007/s11481-015-9615-Z
38. Chiurchiù V, Leuti A, Maccarrone M. Cannabinoid signaling and neuroinflammatory diseases: a melting pot for the regulation of brain immune responses. J Neuroimmune Pharmacol (2015) 10:268-80. doi:10.1007/ s11481-015-9584-2

39. Cabral GA, Ferreira GA, Jamerson MJ. Endocannabinoids and the immune system in health and disease. Handb Exp Pharmacol (2015) 231:185-211. doi:10.1007/978-3-319-20825-1_6

40. Bíró T, Tóth BI, Haskó G, Paus R, Pacher P. The endocannabinoid system of the skin in health and disease: novel perspectives and therapeutic opportunities. Trends Pharmacol Sci (2009) 30:411-20. doi:10.1016/j.tips.2009. 05.004

41. Acharya N, Penukonda S, Shcheglova T, Hagymasi AT, Basu S, Srivastava PK. Endocannabinoid system acts as a regulator of immune homeostasis in the gut. Proc Natl Acad Sci U S A (2017) 114:5005-10. doi:10.1073/pnas.1612177114

42. Butrica JL. The medical use of Cannabis among the Greeks and Romans. J Cannabis Ther (2002) 2:51-70. doi:10.1300/J175v02n02_04

43. Russo EB. Beyond Cannabis: plants and the endocannabinoid system. Trends Pharmacol Sci (2016) 37:594-605. doi:10.1016/j.tips.2016.04.005

44. Gertsch J, Leonti M, Raduner S, Racz I, Chen J-Z, Xie X-Q, et al. Beta-caryophyllene is a dietary cannabinoid. Proc Natl Acad Sci U S A (2008) 105:9099-104. doi:10.1073/pnas.0803601105

45. Elsohly MA, Slade D. Chemical constituents of marijuana: the complex mixture of natural cannabinoids. Life Sci (2005) 78:539-48. doi:10.1016/j. lfs.2005.09.011

46. Gertsch J, Pertwee RG, Di Marzo V. Phytocannabinoids beyond the Cannabis plant - do they exist? Br J Pharmacol (2010) 160:523-9. doi:10.1111/j. 1476-5381.2010.00745.x

47. Russo EB. Taming THC: potential Cannabis synergy and phytocannabinoid-terpenoid entourage effects. Br JPharmacol (2011) 163:1344-64. doi:10.1111/j.1476-5381.2011.01238.x

48. Pertwee RG. The diverse CB1 and CB2 receptor pharmacology of three plant cannabinoids: delta9-tetrahydrocannabinol, cannabidiol and delta9tetrahydrocannabivarin. Br J Pharmacol (2008) 153:199-215. doi:10.1038/ sj.bjp.0707442

49. Cascio MG, Gauson LA, Stevenson LA, Ross RA, Pertwee RG. Evidence that the plant cannabinoid cannabigerol is a highly potent alpha2adrenoceptor agonist and moderately potent $5 \mathrm{HT} 1 \mathrm{~A}$ receptor antagonist. Br J Pharmacol (2010) 159:129-41. doi:10.1111/j.1476-5381.2009.00515.x

50. Zendulka O, Dovrtělová G, Nosková K, Turjap M, Šulcová A, Hanuš L, et al. Cannabinoids and cytochrome P450 interactions. Curr Drug Metab (2016) 17:206-26. doi:10.2174/1389200217666151210142051

51. Colombo D, Lunardon L, Bellia G. Cyclosporine and herbal supplement interactions. J Toxicol (2014) 2014:145325. doi:10.1155/2014/145325

52. Brodie JS, Di Marzo V, Guy GW. Polypharmacology shakes hands with complex aetiopathology. Trends Pharmacol Sci (2015) 36:802-21. doi:10.1016/j. tips.2015.08.010

53. Santoni G, Cardinali C, Morelli MB, Santoni M, Nabissi M, Amantini C. Danger- and pathogen-associated molecular patterns recognition by pattern-recognition receptors and ion channels of the transient receptor potential family triggers the inflammasome activation in immune cells and sensory neurons. J Neuroinflammation (2015) 12:21. doi:10.1186/s12974015-0239-2

54. Parenti A, De Logu F, Geppetti P, Benemei S. What is the evidence for the role of TRP channels in inflammatory and immune cells? Br J Pharmacol (2016) 173:953-69. doi:10.1111/bph.13392

55. O'Sullivan SE, Kendall DA. Cannabinoid activation of peroxisome proliferator-activated receptors: potential for modulation of inflammatory disease. Immunobiology (2010) 215:611-6. doi:10.1016/j.imbio.2009.09.007

56. Moreau A, Alliot-Licht B, Cuturi M-C, Blancho G. Tolerogenic dendritic cell therapy in organ transplantation. Transpl Int (2017) 30:754-64. doi:10.1111/ tri. 12889

57. Zhang C, Wang S, Yang C, Rong R. The crosstalk between myeloid derived suppressor cells and immune cells: to establish immune tolerance in transplantation. J Immunol Res (2016) 2016:4986797. doi:10.1155/2016/ 4986797

58. Romano M, Tung SL, Smyth LA, Lombardi G. Treg therapy in transplantation: a general overview. Transpl Int (2017) 30:745-53. doi:10.1111/tri.12909 
59. Moore CA, Iasella CJ, Venkataramanan R, Lakkis FG, Smith RB, McDyer JF, et al. Janus kinase inhibition for immunosuppression in solid organ transplantation: is there a role in complex immunologic challenges? Hum Immunol (2017) 78:64-71. doi:10.1016/j.humimm.2016.12.005

60. Nagarkatti M, Rieder SA, Hegde VL, Kanada S, Nagarkatti P. Do cannabinoids have a therapeutic role in transplantation? Trends Pharmacol Sci (2010) 31:345-50. doi:10.1016/j.tips.2010.05.006

61. Kemter AM, Scheu S, Hüser N, Ruland C, Schumak B, Findeiß M, et al. The cannabinoid receptor 2 is involved in acute rejection of cardiac allografts. Life Sci (2015) 138:29-34. doi:10.1016/j.lfs.2015.02.012

62. Sido JM, Nagarkatti PS, Nagarkatti M. $\Delta^{9}$-Tetrahydrocannabinol attenuates allogeneic host-versus-graft response and delays skin graft rejection through activation of cannabinoid receptor 1 and induction of myeloidderived suppressor cells. JLeukoc Biol (2015) 98:435-47. doi:10.1189/ jlb.3A0115-030RR

63. Lee W-S, Erdelyi K, Matyas C, Mukhopadhyay P, Varga ZV, Liaudet L, et al. Cannabidiol limits Tcell-mediated chronic autoimmune myocarditis: implications to autoimmune disorders and organ transplantation. Mol Med (2016). doi:10.2119/molmed.2016.00007

64. Pandey R, Hegde VL, Nagarkatti M, Nagarkatti PS. Targeting cannabinoid receptors as a novel approach in the treatment of graft-versus-host disease: evidence from an experimental murine model. J Pharmacol Exp Ther (2011) 338:819-28. doi:10.1124/jpet.111.182717

65. Yeshurun M, Shpilberg O, Herscovici C, Shargian L, Dreyer J, Peck A, et al. Cannabidiol for the prevention of graft-versus-host-disease after allogeneic hematopoietic cell transplantation: results of a phase II study. Biol Blood Marrow Transplant (2015) 21:1770-5. doi:10.1016/j.bbmt.2015. 05.018

66. Pradhan V, Borse V, Ghosh K. PTPN22 gene polymorphisms in autoimmune diseases with special reference to systemic lupus erythematosus disease susceptibility. J Postgrad Med (2010) 56:239-42. doi:10.4103/00223859.68651

67. Sipe JC, Arbour N, Gerber A, Beutler E. Reduced endocannabinoid immune modulation by a common cannabinoid 2 (CB2) receptor gene polymorphism: possible risk for autoimmune disorders. J Leukoc Biol (2005) 78:231-8. doi:10.1189/jlb.0205111

68. Mahmoud Gouda H, Mohamed Kamel NR. Cannabinoid CB2 receptor gene (CNR2) polymorphism is associated with chronic childhood immune thrombocytopenia in Egypt. Blood Coagul Fibrinolysis (2013) 24:247-51. doi:10.1097/MBC.0b013e32835abald

69. Rossi F, Bellini G, Tolone C, Luongo L, Mancusi S, Papparella A, et al. The cannabinoid receptor type 2 Q63R variant increases the risk of celiac disease: implication for a novel molecular biomarker and future therapeutic intervention. Pharmacol Res (2012) 66:88-94. doi:10.1016/j.phrs.2012. 03.011

70. Coppola N, Zampino R, Bellini G, Stanzione M, Capoluongo N, Marrone A, et al. CB2-63 polymorphism and immune-mediated diseases associated with HCV chronic infection. Dig Liver Dis (2016) 48:1364-9. doi:10.1016/j.dld.2016.07.005

71. Coppola N, Zampino R, Bellini G, Macera M, Marrone A, Pisaturo M, et al. Association between a polymorphism in cannabinoid receptor 2 and severe necroinflammation in patients with chronic hepatitis C. Clin Gastroenterol Hepatol (2014) 12:334-40. doi:10.1016/j.cgh.2013.05.008

72. Gui H, Tong Q, Qu W, Mao C-M, Dai S-M. The endocannabinoid system and its therapeutic implications in rheumatoid arthritis. Int Immunopharmacol (2015) 26:86-91. doi:10.1016/j.intimp.2015.03.006

73. Fitzcharles M-A, McDougall J, Ste-Marie PA, Padjen I. Clinical implications for cannabinoid use in the rheumatic diseases: potential for help or harm? Arthritis Rheum (2012) 64:2417-25. doi:10.1002/art.34522

74. Sido JM, Nagarkatti PS, Nagarkatti M. Role of endocannabinoid activation of peripheral CB1 receptors in the regulation of autoimmune disease. Int Rev Immunol (2015) 34:403-14. doi:10.3109/08830185.2014.921165

75. Katchan V, David P, Shoenfeld Y. Cannabinoids and autoimmune diseases: a systematic review. Autoimmun Rev (2016) 15:513-28. doi:10.1016/j.autrev. 2016.02.008

76. Li X, Kaminski NE, Fischer LJ. Examination of the immunosuppressive effect of delta9-tetrahydrocannabinol in streptozotocin-induced autoimmune diabetes. Int Immunopharmacol (2001) 1:699-712. doi:10.1016/ S1567-5769(01)00003-0
77. Marquéz L, Suárez J, Iglesias M, Bermudez-Silva FJ, Rodríguez de Fonseca F, Andreu M. Ulcerative colitis induces changes on the expression of the endocannabinoid system in the human colonic tissue. PLoS One (2009) 4:e6893. doi:10.1371/journal.pone.0006893

78. Naftali T, Mechulam R, Lev LB, Konikoff FM. Cannabis for inflammatory bowel disease. Dig Dis (2014) 32:468-74. doi:10.1159/000358155

79. Wright KL, Duncan M, Sharkey KA. Cannabinoid CB2 receptors in the gastrointestinal tract: a regulatory system in states of inflammation. Br J Pharmacol (2008) 153:263-70. doi:10.1038/sj.bjp.0707486

80. Katz D, Katz I, Porat-Katz BS, Shoenfeld Y. Medical Cannabis: another piece in the mosaic of autoimmunity? Clin Pharmacol Ther (2017) 101:230-8. doi: $10.1002 /$ cpt.568

81. Lehmann C, Fisher NB, Tugwell B, Szczesniak A, Kelly M, Zhou J. Experimental cannabidiol treatment reduces early pancreatic inflammation in type 1 diabetes. Clin Hemorheol Microcirc (2016) 64:655-62. doi:10.3233/ CH-168021

82. Centonze D, Bari M, Rossi S, Prosperetti C, Furlan R, Fezza F, et al. The endocannabinoid system is dysregulated in multiple sclerosis and in experimental autoimmune encephalomyelitis. Brain (2007) 130:2543-53. doi:10.1093/brain/awm160

83. Sexton M, Cudaback E, Abdullah RA, Finnell J, Mischley LK, Rozga M, et al. Cannabis use by individuals with multiple sclerosis: effects on specific immune parameters. Inflammopharmacology (2014) 22:295-303. doi:10.1007/s10787-014-0214-z

84. Fitzpatrick J-MK, Downer EJ. Toll-like receptor signalling as a cannabinoid target in multiple sclerosis. Neuropharmacology (2016) 113:618-26. doi:10.1016/j.neuropharm.2016.04.009

85. Haugh O, Penman J, Irving AJ, Campbell VA. The emerging role of the cannabinoid receptor family in peripheral and neuro-immune interactions. Curr Drug Targets (2016) 17:1834-40. doi:10.2174/1389450117666160112 113703

86. Molina-Holgado F, Molina-Holgado E, Guaza C. The endogenous cannabinoid anandamide potentiates interleukin- 6 production by astrocytes infected with Theiler's murine encephalomyelitis virus by a receptormediated pathway. FEBS Lett (1998) 433:139-42. doi:10.1016/S0014-5793 (98)00851-5

87. Ribeiro R, Yu F, Wen J, Vana A, Zhang Y. Therapeutic potential of a novel cannabinoid agent CB52 in the mouse model of experimental autoimmune encephalomyelitis. Neuroscience (2013) 254:427-42. doi:10.1016/j. neuroscience.2013.09.005

88. Lourbopoulos A, Grigoriadis N, Lagoudaki R, Touloumi O, Polyzoidou E, Mavromatis I, et al. Administration of 2-arachidonoylglycerol ameliorates both acute and chronic experimental autoimmune encephalomyelitis. Brain Res (2011) 1390:126-41. doi:10.1016/j.brainres.2011. 03.020

89. Maresz K, Carrier EJ, Ponomarev ED, Hillard CJ, Dittel BN. Modulation of the cannabinoid CB2 receptor in microglial cells in response to inflammatory stimuli. J Neurochem (2005) 95:437-45. doi:10.1111/j.1471-4159.2005. 03380.x

90. Lou Z-Y, Chen C, He Q, Zhao C-B, Xiao B-G. Targeting CB(2) receptor as a neuroinflammatory modulator in experimental autoimmune encephalomyelitis. Mol Immunol (2011) 49:453-61. doi:10.1016/j.molimm.2011. 09.016

91. Kong W, Li H, Tuma RF, Ganea D. Selective CB2 receptor activation ameliorates EAE by reducing Th17 differentiation and immune cell accumulation in the CNS. Cell Immunol (2014) 287:1-17. doi:10.1016/j.cellimm. 2013.11.002

92. Shi Y, Duan Y-H, Ji Y-Y, Wang Z-L, Wu Y-R, Gunosewoyo H, et al. Amidoalkylindoles as potent and selective cannabinoid type 2 receptor agonists with in vivo efficacy in a mouse model of multiple sclerosis. J Med Chem (2017) 60:7067-83. doi:10.1021/acs.jmedchem.7b00724

93. Annunziata P, Cioni C, Mugnaini C, Corelli F. Potent immunomodulatory activity of a highly selective cannabinoid CB2 agonist on immune cells from healthy subjects and patients with multiple sclerosis. J Neuroimmunol (2017) 303:66-74. doi:10.1016/j.jneuroim.2016.12.009

94. Morales P, Gómez-Cañas M, Navarro G, Hurst DP, Carrillo-Salinas FJ, Lagartera L, et al. Chromenopyrazole, a versatile cannabinoid scaffold with in vivo activity in a model of multiple sclerosis. J Med Chem (2016) 59:6753-71. doi:10.1021/acs.jmedchem.6b00397 
95. Malfitano AM, Laezza C, Pisanti S, Manera C, Bifulco M. Immunomodulatory properties of a quinolin-2-(1H)-on-3-carboxamide derivative: relevance in multiple sclerosis. Recent Pat CNS Drug Discov (2016) 10:113-21. doi:10.2174/1574889810666160421121726

96. Correa F, Hernangómez M, Mestre L, Loría F, Spagnolo A, Docagne F, et al. Anandamide enhances IL-10 production in activated microglia by targeting $\mathrm{CB}(2)$ receptors: roles of ERK1/2, JNK, and NF-kappaB. Glia (2010) 58:135-47. doi:10.1002/glia.20907

97. Correa F, Hernangómez-Herrero M, Mestre L, Loría F, Docagne F, Guaza C. The endocannabinoid anandamide downregulates IL-23 and IL-12 subunits in a viral model of multiple sclerosis: evidence for a cross-talk between IL-12p70/IL-23 axis and IL-10 in microglial cells. Brain Behav Immun (2011) 25:736-49. doi:10.1016/j.bbi.2011.01.020

98. Correa F, Docagne F, Mestre L, Loría F, Hernangómez M, Borrell J, et al. Cannabinoid system and neuroinflammation: implications for multiple sclerosis. Neuroimmunomodulation (2007) 14:182-7. doi:10.1159/ 000110644

99. Ramirez SH, Haskó J, Skuba A, Fan S, Dykstra H, McCormick R, et al. Activation of cannabinoid receptor 2 attenuates leukocyte-endothelial cell interactions and blood-brain barrier dysfunction under inflammatory conditions. J Neurosci (2012) 32:4004-16. doi:10.1523/JNEUROSCI.462811.2012

100. Mecha M, Carrillo-Salinas FJ, Feliú A, Mestre L, Guaza C. Microglia activation states and cannabinoid system: therapeutic implications. Pharmacol Ther (2016) 166:40-55. doi:10.1016/j.pharmthera.2016.06.011

101. Carrillo-Salinas FJ, Navarrete C, Mecha M, Feliú A, Collado JA, Cantarero I, et al. A cannabigerol derivative suppresses immune responses and protects mice from experimental autoimmune encephalomyelitis. PLoS One (2014) 9:e94733. doi:10.1371/journal.pone.0094733

102. Alberti TB, Barbosa WLR, Vieira JLF, Raposo NRB, Dutra RC. (-)- $\beta$ caryophyllene, a CB2 receptor-selective phytocannabinoid, suppresses motor paralysis and neuroinflammation in a murine model of multiple sclerosis. Int J Mol Sci (2017) 18. doi:10.3390/ijms18040691

103. Pertwee RG. Cannabinoid pharmacology: the first 66 years. Br J Pharmacol (2006) 147(Suppl 1):S163-71. doi:10.1038/sj.bjp.0706406

104. Patti F, Messina S, Solaro C, Amato MP, Bergamaschi R, Bonavita S, et al. Efficacy and safety of cannabinoid oromucosal spray for multiple sclerosis spasticity. J Neurol Neurosurg Psychiatry (2016) 87:944-51. doi:10.1136/ jnnp-2015-312591

105. Lanza G, Ferri R, Bella R, Ferini-Strambi L. The impact of drugs for multiple sclerosis on sleep. Mult Scler (2017) 23:5-13. doi:10.1177/1352458516664034

106. Marinelli L, Mori L, Canneva S, Colombano F, Currà A, Fattapposta F, et al. The effect of cannabinoids on the stretch reflex in multiple sclerosis spasticity. Int Clin Psychopharmacol (2016) 31:232-9. doi:10.1097/YIC. 0000000000000126

107. van Amerongen G, Kanhai K, Baakman AC, Heuberger J, Klaassen E, Beumer TL, et al. Effects on spasticity and neuropathic pain of an oral formulation of $\Delta$ 9-tetrahydrocannabinol in patients with progressive multiple sclerosis. Clin Ther (2017). doi:10.1016/j.clinthera.2017.01.016

108. Abo Youssef N, Schneider MP, Mordasini L, Ineichen BV, Bachmann LM, Chartier-Kastler E, et al. Cannabinoids for treating neurogenic lower urinary tract dysfunction in patients with multiple sclerosis: a systematic review and meta-analysis. BJU Int (2017) 119:515-21. doi:10.1111/bju. 13759

109. Maccarrone M, Maldonado R, Casas M, Henze T, Centonze D. Cannabinoids therapeutic use: what is our current understanding following the introduction of THC, THC:CBD oromucosal spray and others? Expert Rev Clin Pharmacol (2017) 10:443-55. doi:10.1080/17512433.2017. 1292849

110. Behm K, Morgan P. The effect of symptom-controlling medication on gait outcomes in people with multiple sclerosis: a systematic review. Disabil Rehabil (2017) 4:1-12. doi:10.1080/09638288.2017.1309581

111. Squintani G, Donato F, Turri M, Deotto L, Teatini F, Moretto G, et al. Cortical and spinal excitability in patients with multiple sclerosis and spasticity after oromucosal cannabinoid spray. J Neurol Sci (2016) 370:263-8. doi:10.1016/j.jns.2016.09.054

112. Meza R, Peña J, García K, Corsi O, Rada G. Are cannabinoids effective in multiple sclerosis? Medwave (2017) 17:e6865. doi:10.5867/medwave. 2017.6865
113. Katona S, Kaminski E, Sanders H, Zajicek J. Cannabinoid influence on cytokine profile in multiple sclerosis. Clin Exp Immunol (2005) 140:580-5. doi:10.1111/j.1365-2249.2005.02803.x

114. Cannabinoid Buccal Spray for Chronic Non-Cancer or Neuropathic Pain: A Review of Clinical Effectiveness, Safety, and Guidelines. Ottawa, ON: Canadian Agency for Drugs and Technologies in Health (2016). Available from: http://www.ncbi.nlm.nih.gov/books/NBK395789/

115. Saccà F, Pane C, Carotenuto A, Massarelli M, Lanzillo R, Florio EB, et al. The use of medical-grade Cannabis in patients non-responders to nabiximols. J Neurol Sci (2016) 368:349-51. doi:10.1016/j.jns.2016.07.059

116. Lyman WD, Sonett JR, Brosnan CF, Elkin R, Bornstein MB. Delta 9tetrahydrocannabinol: a novel treatment for experimental autoimmune encephalomyelitis. J Neuroimmunol (1989) 23:73-81. doi:10.1016/01655728(89)90075-1

117. Pryce G, Riddall DR, Selwood DL, Giovannoni G, Baker D. Neuroprotection in experimental autoimmune encephalomyelitis and progressive multiple sclerosis by Cannabis-based cannabinoids. J Neuroimmune Pharmacol (2015) 10:281-92. doi:10.1007/s11481-014-9575-8

118. Giacoppo S, Pollastro F, Grassi G, Bramanti P, Mazzon E. Target regulation of PI3K/Akt/mTOR pathway by cannabidiol in treatment of experimental multiple sclerosis. Fitoterapia (2017) 116:77-84. doi:10.1016/j.fitote.2016. 11.010

119. Kozela E, Juknat A, Gao F, Kaushansky N, Coppola G, Vogel Z. Pathways and gene networks mediating the regulatory effects of cannabidiol, a nonpsychoactive cannabinoid, in autoimmune T cells. JNeuroinflammation (2016) 13:136. doi:10.1186/s12974-016-0603-x

120. Mecha M, Feliú A, Iñigo PM, Mestre L, Carrillo-Salinas FJ, Guaza C. Cannabidiol provides long-lasting protection against the deleterious effects of inflammation in a viral model of multiple sclerosis: a role for A2A receptors. Neurobiol Dis (2013) 59:141-50. doi:10.1016/j.nbd.2013. 06.016

121. Ribeiro A, Ferraz-de-Paula V, Pinheiro ML, Vitoretti LB, Mariano-Souza DP, Quinteiro-Filho WM, et al. Cannabidiol, a non-psychotropic plant-derived cannabinoid, decreases inflammation in a murine model of acute lung injury: role for the adenosine A(2A) receptor. Eur J Pharmacol (2012) 678:78-85. doi:10.1016/j.ejphar.2011.12.043

122. Oláh A, Tóth BI, Borbíró I, Sugawara K, Szöllõsi AG, Czifra G, et al. Cannabidiol exerts sebostatic and antiinflammatory effects on human sebocytes. J Clin Invest (2014) 124:3713-24. doi:10.1172/JCI64628

123. Carrier EJ, Auchampach JA, Hillard CJ. Inhibition of an equilibrative nucleoside transporter by cannabidiol: a mechanism of cannabinoid immunosuppression. Proc Natl Acad Sci U S A (2006) 103:7895-900. doi:10.1073/pnas. 0511232103

124. Birdsall SM, Birdsall TC, Tims LA. The use of medical marijuana in cancer. Curr Oncol Rep (2016) 18:40. doi:10.1007/s11912-016-0530-0

125. Velasco G, Sánchez C, Guzmán M. Anticancer mechanisms of cannabinoids. Curr Oncol (2016) 23:S23-32. doi:10.3747/co.23.3080

126. Nikan M, Nabavi SM, Manayi A. Ligands for cannabinoid receptors, promising anticancer agents. Life Sci (2016) 146:124-30. doi:10.1016/j.lfs. 2015.12.053

127. Velasco G, Sánchez C, Guzmán M. Endocannabinoids and cancer. Handb Exp Pharmacol (2015) 231:449-72. doi:10.1007/978-3-319-20825-1_16

128. Velasco G, Hernández-Tiedra S, Dávila D, Lorente M. The use of cannabinoids as anticancer agents. Prog Neuropsychopharmacol Biol Psychiatry (2016) 64:259-66. doi:10.1016/j.pnpbp.2015.05.010

129. McAllister SD, Soroceanu L, Desprez P-Y. The antitumor activity of plantderived non-psychoactive cannabinoids. J Neuroimmune Pharmacol (2015) 10:255-67. doi:10.1007/s11481-015-9608-y

130. Pyszniak M, Tabarkiewicz J, Łuszczki JJ. Endocannabinoid system as a regulator of tumor cell malignancy - biological pathways and clinical significance. Onco Targets Ther (2016) 9:4323-36. doi:10.2147/OTT.S106944

131. Ramer R, Hinz B. Antitumorigenic targets of cannabinoids - current status and implications. Expert Opin Ther Targets (2016) 20:1219-35. doi:10.1080/ 14728222.2016.1177512

132. Javid FA, Phillips RM, Afshinjavid S, Verde R, Ligresti A. Cannabinoid pharmacology in cancer research: a new hope for cancer patients? Eur J Pharmacol (2016) 775:1-14. doi:10.1016/j.ejphar.2016.02.010

133. Tegeder I. Endocannabinoids as guardians of metastasis. Int J Mol Sci (2016) 17:230. doi:10.3390/ijms17020230 
134. Fraguas-Sánchez AI, Fernández-Carballido A, Torres-Suárez AI. Phyto-, endo- and synthetic cannabinoids: promising chemotherapeutic agents in the treatment of breast and prostate carcinomas. Expert Opin Investig Drugs (2016) 25:1311-23. doi:10.1080/13543784.2016.1236913

135. Carpi S, Fogli S, Polini B, Montagnani V, Podestà A, Breschi MC, et al. Tumor-promoting effects of cannabinoid receptor type 1 in human melanoma cells. Toxicol In Vitro (2017) 40:272-9. doi:10.1016/j.tiv.2017.01.018

136. Wang J, Xu Y, Zou Y, Zhu L, Dong B, Huang J, et al. Overexpression of cannabinoid receptor 1 promotes renal cell carcinoma progression. Tumour Biol (2016) 37(12):16237-47. doi:10.1007/s13277-016-5447-6

137. Martínez-Martínez E, Martín-Ruiz A, Martín P, Calvo V, Provencio M, García JM. CB2 cannabinoid receptor activation promotes colon cancer progression via AKT/GSK3 $\beta$ signaling pathway. Oncotarget (2016) 7:68781-91. doi:10.18632/oncotarget.11968

138. Pokrywka M, Góralska J, Solnica B. Cannabinoids - a new weapon against cancer? Postepy Hig Med Dosw (Online) (2016) 70:1309-20. doi:10.5604/ 17322693.1227443

139. Ladin DA, Soliman E, Griffin L, Van Dross R. Preclinical and clinical assessment of cannabinoids as anti-cancer agents. Front Pharmacol (2016) 7:361. doi:10.3389/fphar.2016.00361

140. McKallip RJ, Nagarkatti M, Nagarkatti PS. Delta-9-tetrahydrocannabinol enhances breast cancer growth and metastasis by suppression of the antitumor immune response. J Immunol (2005) 174:3281-9. doi:10.4049/ jimmunol.174.6.3281

141. Gao W, Xiong Y, Li Q, Yang H. Inhibition of toll-like receptor signaling as a promising therapy for inflammatory diseases: a journey from molecular to nano therapeutics. Front Physiol (2017) 8:508. doi:10.3389/fphys.2017. 00508

142. Fang H, Jiang W, Cheng J, Lu Y, Liu A, Kan L, et al. Balancing innate immunity and inflammatory state via modulation of neutrophil function: a novel strategy to fight sepsis. J Immunol Res (2015) 2015:187048. doi:10.1155/2015/ 187048

143. Sivak KV, Vasin AV, Egorov VV, Tsevtkov VB, Kuzmich NN, Savina VA, et al. [Adenosine A2A receptor as a drug target for treatment of sepsis]. Mol Biol (Mosk) (2016) 50:231-45. doi:10.7868/S0026898416020233

144. Sardinha J, Kelly MEM, Zhou J, Lehmann C. Experimental cannabinoid 2 receptor-mediated immune modulation in sepsis. Mediators Inflamm (2014) 2014:978678. doi:10.1155/2014/978678

145. Tschöp J, Kasten KR, Nogueiras R, Goetzman HS, Cave CM, England LG, et al. The cannabinoid receptor 2 is critical for the host response to sepsis. J Immunol (2009) 183:499-505. doi:10.4049/jimmunol.0900203

146. Croxford JL, Wang K, Miller SD, Engman DM, Tyler KM. Effects of cannabinoid treatment on Chagas disease pathogenesis: balancing inhibition of parasite invasion and immunosuppression. Cell Microbiol (2005) 7:1592-602. doi:10.1111/j.1462-5822.2005.00577.x

147. Alferink J, Specht S, Arends H, Schumak B, Schmidt K, Ruland C, et al. Cannabinoid receptor 2 modulates susceptibility to experimental cerebral malaria through a CCL17-dependent mechanism. JBiol Chem (2016) 291:19517-31. doi:10.1074/jbc.M116.746594

148. Sun X, Cappelletti M, Li Y, Karp CL, Divanovic S, Dey SK. Cnr2 deficiency confers resistance to inflammation-induced preterm birth in mice. Endocrinology (2014) 155:4006-14. doi:10.1210/en.2014-1387

149. Dotsey E, Ushach I, Pone E, Nakajima R, Jasinskas A, Argueta DA, et al. Transient cannabinoid receptor 2 blockade during immunization heightens intensity and breadth of antigen-specific antibody responses in young and aged mice. Sci Rep (2017) 7:42584. doi:10.1038/srep42584

150. Appendino G, Gibbons S, Giana A, Pagani A, Grassi G, Stavri M, et al. Antibacterial cannabinoids from Cannabis sativa: a structure-activity study. J Nat Prod (2008) 71:1427-30. doi:10.1021/np8002673

151. Tahamtan A, Tavakoli-Yaraki M, Rygiel TP, Mokhtari-Azad T, Salimi V. Effects of cannabinoids and their receptors on viral infections. J Med Virol (2016) 88:1-12. doi:10.1002/jmv.24292

152. Barichello T, Ceretta RA, Generoso JS, Moreira AP, Simões LR, Comim CM, et al. Cannabidiol reduces host immune response and prevents cognitive impairments in Wistar rats submitted to pneumococcal meningitis. Eur J Pharmacol (2012) 697:158-64. doi:10.1016/j.ejphar.2012.09.053

153. Chandra LC, Kumar V, Torben W, Vande Stouwe C, Winsauer P, Amedee A, et al. Chronic administration of $\Delta 9$-tetrahydrocannabinol induces intestinal anti-inflammatory microRNA expression during acute simian immunodeficiency virus infection of rhesus macaques. J Virol (2015) 89:1168-81. doi:10.1128/JVI.01754-14

154. Simon L, Song K, Vande Stouwe C, Hollenbach A, Amedee A, Mohan M, et al. $\Delta 9$-Tetrahydrocannabinol $(\Delta 9$-THC) promotes neuroimmunemodulatory microRNA profile in striatum of simian immunodeficiency virus (SIV)-infected macaques. J Neuroimmune Pharmacol (2016) 11: 192-213. doi:10.1007/s11481-015-9645-6

155. Molina PE, Winsauer P, Zhang P, Walker E, Birke L, Amedee A, et al. Cannabinoid administration attenuates the progression of simian immunodeficiency virus. AIDS Res Hum Retroviruses (2011) 27:585-92. doi:10.1089/aid.2010.0218

156. Chen W, Crawford RB, Kaplan BLF, Kaminski NE. Modulation of HIVGP120 antigen-specific immune responses in vivo by $\Delta 9$-tetrahydrocannabinol. J NeuroimmunePharmacol(2015) 10:344-55.doi:10.1007/s11481-015-9597-x

157. Marcellin F, Lions C, Rosenthal E, Roux P, Sogni P, Wittkop L, et al. No significant effect of Cannabis use on the count and percentage of circulating CD4 T-cells in HIV-HCV co-infected patients (ANRS CO13HEPAVIH French cohort). Drug Alcohol Rev (2017) 36:227-38. doi:10.1111/ dar. 12398

158. Molina PE, Amedee A, LeCapitaine NJ, Zabaleta J, Mohan M, Winsauer P, et al. Cannabinoid neuroimmune modulation of SIV disease. JNeuroimmune Pharmacol (2011) 6:516-27. doi:10.1007/s11481-011-9301-8

159. Reznik SE, Gardner EL, Ashby CR. Cannabidiol: a potential treatment for post Ebola syndrome? Int J Infect Dis (2016) 52:74-6. doi:10.1016/j. ijid.2016.09.020

160. Lowe HIC, Toyang NJ, McLaughlin W. Potential of cannabidiol for the treatment of viral hepatitis. Pharmacognosy Res (2017) 9:116-8. doi:10.4103/ 0974-8490.199780

161. Campos AC, Brant F, Miranda AS, Machado FS, Teixeira AL. Cannabidiol increases survival and promotes rescue of cognitive function in a murine model of cerebral malaria. Neuroscience (2015) 289:166-80. doi:10.1016/j.neuroscience.2014.12.051

162. Blumstein GW, Parsa A, Park AK, McDowell BLP, Arroyo-Mendoza M, Girguis M, et al. Effect of delta-9-tetrahydrocannabinol on mouse resistance to systemic Candida albicans infection. PLoS One (2014) 9:e103288. doi:10.1371/journal.pone.0103288

163. Newton CA, Chou P-J, Perkins I, Klein TW. CB(1) and CB(2) cannabinoid receptors mediate different aspects of delta-9-tetrahydrocannabinol (THC)induced $\mathrm{T}$ helper cell shift following immune activation by Legionella pneumophila infection. J Neuroimmune Pharmacol (2009) 4:92-102. doi:10.1007/ s11481-008-9126-2

164. Karmaus PWF, Chen W, Crawford R, Kaplan BLF, Kaminski NE. $\Delta 9$ tetrahydrocannabinol impairs the inflammatory response to influenza infection: role of antigen-presenting cells and the cannabinoid receptors 1 and 2. Toxicol Sci (2013) 131:419-33. doi:10.1093/toxsci/kfs315

165. Roth MD, Tashkin DP, Whittaker KM, Choi R, Baldwin GC. Tetrahydrocannabinol suppresses immune function and enhances HIV replication in the huPBL-SCID mouse. Life Sci (2005) 77:1711-22. doi:10.1016/j. lfs.2005.05.014

166. Henriquez JE, Rizzo MD, Schulz MA, Crawford RB, Gulick P, Kaminski NE. $\Delta$ 9-tetrahydrocannabinol suppresses secretion of IFN $\alpha$ by plasmacytoid dendritic cells from healthy and HIV-infected individuals. J Acquir Immune Defic Syndr (2017) 75:588-96. doi:10.1097/QAI.0000000000001449

167. Roth MD, Baldwin GC, Tashkin DP. Effects of delta-9-tetrahydrocannabinol on human immune function and host defense. Chem Phys Lipids (2002) 121:229-39. doi:10.1016/S0009-3084(02)00159-7

168. Zumbrun EE, Sido JM, Nagarkatti PS, Nagarkatti M. Epigenetic regulation of immunological alterations following prenatal exposure to marijuana cannabinoids and its long term consequences in offspring. J Neuroimmune Pharmacol (2015) 10:245-54. doi:10.1007/s11481-015-9586-0

169. Lombard C, Hegde VL, Nagarkatti M, Nagarkatti PS. Perinatal exposure to $\Delta$ 9-tetrahydrocannabinol triggers profound defects in $\mathrm{T}$ cell differentiation and function in fetal and postnatal stages of life, including decreased responsiveness to HIV antigens. J Pharmacol Exp Ther (2011) 339:607-17. doi:10.1124/jpet.111.181206

170. Moretti S, Franchi S, Castelli M, Amodeo G, Somaini L, Panerai A, et al. Exposure of adolescent mice to delta-9-tetrahydrocannabinol induces 
long-lasting modulation of pro- and anti-inflammatory cytokines in hypothalamus and hippocampus similar to that observed for peripheral macrophages. J Neuroimmune Pharmacol (2015) 10:371-9. doi:10.1007/ s11481-015-9592-2

171. Moretti S, Castelli M, Franchi S, Raggi MA, Mercolini L, Protti M, et al. $\Delta^{9}$-Tetrahydrocannabinol-induced anti-inflammatory responses in adolescent mice switch to proinflammatory in adulthood. J Leukoc Biol (2014) 96:523-34. doi:10.1189/jlb.3HI0713-406RR

172. Dax EM, Pilotte NS, Adler WH, Nagel JE, Lange WR. The effects of 9-enetetrahydrocannabinol on hormone release and immune function. J Steroid Biochem (1989) 34:263-70. doi:10.1016/0022-4731(89)90090-3

173. Utomo WK, de Vries M, Braat H, Bruno MJ, Parikh K, Comalada M, et al. Modulation of human peripheral blood mononuclear cell signaling by medicinal cannabinoids. Front Mol Neurosci (2017) 10:14. doi:10.3389/ fnmol.2017.00014

174. El-Gohary M, Eid MA. Effect of cannabinoid ingestion (in the form of bhang) on the immune system of high school and university students. Hum Exp Toxicol (2004) 23:149-56. doi:10.1191/0960327104ht426oa

175. Bénard G, Massa F, Puente N, Lourenço J, Bellocchio L, Soria-Gómez E, et al. Mitochondrial $\mathrm{CB}_{1}$ receptors regulate neuronal energy metabolism. Nat Neurosci (2012) 15:558-64. doi:10.1038/nn.3053

176. Hebert-Chatelain E, Desprez T, Serrat R, Bellocchio L, Soria-Gomez E, Busquets-Garcia A, et al. A cannabinoid link between mitochondria and memory. Nature (2016) 539:555-9. doi:10.1038/nature20127

177. Bilkei-Gorzo A, Albayram O, Draffehn A, Michel K, Piyanova A, Oppenheimer H, et al. A chronic low dose of $\Delta(9)$-tetrahydrocannabinol (THC) restores cognitive function in old mice. Nat Med (2017) 23:782-7. doi:10.1038/nm.4311

178. Bilkei-Gorzo A, Drews E, Albayram Ö, Piyanova A, Gaffal E, Tueting T, et al. Early onset of aging-like changes is restricted to cognitive abilities and skin structure in $\mathrm{Cnr1}^{-l^{-}}$mice. Neurobiol Aging (2012) 33:200.e11-22. doi:10.1016/j.neurobiolaging.2010.07.009

179. Dudok B, Barna L, Ledri M, Szabó SI, Szabadits E, Pintér B, et al. Cell-specific STORM super-resolution imaging reveals nanoscale organization of cannabinoid signaling. Nat Neurosci (2015) 18:75-86. doi:10.1038/ nn.3892
180. Topol EJ, Bousser M-G, Fox KAA, Creager MA, Despres J-P, Easton JD, et al. Rimonabant for prevention of cardiovascular events (CRESCENDO): a randomised, multicentre, placebo-controlled trial. Lancet (2010) 376: 517-23. doi:10.1016/S0140-6736(10)60935-X

181. von Schaper E. Bial incident raises FAAH suspicions. Nat Biotechnol (2016) 34:223. doi:10.1038/nbt0316-223a

182. van Esbroeck ACM, Janssen APA, Cognetta AB, Ogasawara D, Shpak G, van der Kroeg $M$, et al. Activity-based protein profiling reveals off-target proteins of the FAAH inhibitor BIA 10-2474. Science (2017) 356:1084-7. doi:10.1126/science.aaf7497

183. Scott KA, Dalgleish AG, Liu WM. Anticancer effects of phytocannabinoids used with chemotherapy in leukaemia cells can be improved by altering the sequence of their administration. Int JOncol (2017) 51:369-77. doi:10.3892/ijo.2017.4022

184. Agudelo M, Figueroa G, Yndart A, Casteleiro G, Muñoz K, Samikkannu T, et al. Alcohol and cannabinoids differentially affect HIV infection and function of human monocyte-derived dendritic cells (MDDC). Front Microbiol (2015) 6:1452. doi:10.3389/fmicb.2015.01452

185. Patterson Z, Young M, Vaccarino F. Novel psychoactive substances: what educators need to know. Clin Pharmacol Ther (2017) 101:173-5. doi:10.1002/ cpt.538

186. Sexton M, Silvestroni A, Möller T, Stella N. Differential migratory properties of monocytes isolated from human subjects naive and non-naive to Cannabis. Inflammopharmacology (2013) 21:253-9. doi:10.1007/s10787-0120133-9

Conflict of Interest Statement: The authors declare that the research was conducted in the absence of any commercial or financial relationships that could be construed as a potential conflict of interest.

Copyright $\odot 2017$ Oláh, Szekanecz and Bíró. This is an open-access article distributed under the terms of the Creative Commons Attribution License (CC BY). The use, distribution or reproduction in other forums is permitted, provided the original author(s) or licensor are credited and that the original publication in this journal is cited, in accordance with accepted academic practice. No use, distribution or reproduction is permitted which does not comply with these terms. 